\title{
Critical Metals Ga, Ge and In: Experimental Evidence for Smelter Recovery Improvements
}

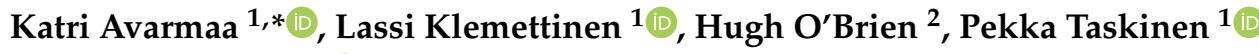 \\ and Ari Jokilaakso ${ }^{1}$ D \\ 1 Department of Chemical and Metallurgical Engineering, Aalto University, Kemistintie 1, P.O. Box 16100, \\ FI-00076 Aalto, Finland; lassi.klemettinen@aalto.fi (L.K.); pekka.taskinen@aalto.fi (P.T.); \\ ari.jokilaakso@aalto.fi (A.J.) \\ 2 Geological Survey of Finland (GTK), Betonimiehenkuja 4, 02150 Espoo, Finland; hugh.obrien@gtk.fi \\ * Correspondence: katri.avarmaa@aalto.fi; Tel.: +358-44-561-9018
}

Received: 15 April 2019; Accepted: 15 June 2019; Published: 18 June 2019

\begin{abstract}
High-tech metals, including Ga, Ge and In, are critical for the performance of electrical and electronic equipment (EEE). None of these three metals exist in mineable levels in natural minerals, and thus their availability and production are dependent on the primary and secondary base metals (including $\mathrm{Zn}, \mathrm{Al}$ and $\mathrm{Cu}$ ) production. To secure the supply of high-tech metals in the future, their behavior, including distribution coefficients $\left(\mathrm{L}^{\mathrm{Cu} / \mathrm{s}}=[\mathrm{wt} \% \mathrm{M}]_{\text {in copper }} /(\mathrm{wt} \% \mathrm{M})_{\text {in slag }}\right)$, in primary and secondary processes need to be characterized. This study reports three series of copper-slag distribution experiments for $\mathrm{Ga}, \mathrm{Ge}$ and $\mathrm{In}$ in simulated secondary copper smelting and refining process conditions $\left(\mathrm{T}=1300^{\circ} \mathrm{C}, \mathrm{pO}_{2}=10^{-9}-10^{-5} \mathrm{~atm}\right)$ using a well-developed drop-quench technique followed by EPMA and LA-ICP-MS analyses. This study shows how an analytical technique more traditionally applied to the characterization of ores or minerals can also be applied to metallurgical process investigation. The LA-ICP-MS analysis was used for the first time for measuring the concentrations of these minor elements in metallurgical glasses, i.e., slags, and the results were compared to the geological literature. The distribution coefficient of indium increased as a function of decreasing oxygen partial pressure from 0.03 to 10, whereas the distribution coefficient of gallium was 0.1 at $10^{-9} \mathrm{~atm}$ and decreased as the $\mathrm{pO}_{2}$ increased. The concentrations of gallium in slags were between 0.4 and $0.6 \mathrm{wt} \%$ and germanium around $1 \mathrm{ppm}$. Germanium was vaporized almost entirely from the samples.
\end{abstract}

Keywords: trace elements; black copper; recycling; LA-ICP-MS

\section{Introduction}

Today's industrialized world is dependent on advanced technology. The increase in wealth and well-being of people is largely achieved by spreading and developing technology and technical innovations. New and specialized properties in electronic equipment (EEE), including artificial intelligence (AI) and improved processing capabilities, require sustainable and sophistically tailored material solutions. This means that new materials and precious as well as rare elements are employed in increasing quantities to fulfill the demand on the range of metal alloy properties in EEE. Simultaneously, primary ore resources are becoming depleted, and new metal sources must be found. This has created a need to improve and develop recycling and recovery processes of critical metals from obsolete EEE and other wastes. Consequently, studies investigating critical element contents in WEEE (Waste EEE) and WEEE recycling practices have become popular subjects in environmental sciences [1-5]. Basically, all metal scrap fractions are treated in base metal smelting facilities. Thus, fundamental knowledge on the thermodynamic properties of minor elements in these smelting processes is critical for the 
improvement of metal recoveries. The experimental observations and data measured in this study provide information on minor element behavior and their recovery possibilities, as well as process development suggestions for industry. Furthermore, these types of data are applicable for database development in modeling and simulation programs.

Base metals have been recycled (to some extent) for hundreds or even thousands of years. Naturally, they still form the basis for metal recycling, and only limited quantities of minor elements are recycled. Typically, the minor elements recovered are the ones existing in sufficient quantities in the raw materials and/or have a strong affinity towards a specific phase or material stream, wherefrom they can be recovered relatively easily and efficiently. However, multiple other rare and special metals that are critical for our society, such as Ga and Ge, are still lacking proper recycling processes and their overall recycling rates are practically zero. Few advanced, integrated state-of-the-art recycling facilities [6,7] exist, which recover multiple minor elements in addition to the base metals. In these integrated factories, the recovery of metals is based on different base metal smelting processes that interact with each other. Minor elements have different thermodynamic properties and tendencies towards different carrier metals in each metal smelting process and stage [8,9]. This type of state-of-the-art recycling approach should be expanded around the world and broadened to cover the recovery of multiple minor critical metals.

The distribution studies on Ga, Ge and In found in the literature for pyrometallurgical copper-slag systems have been described previously $[10,11]$. In addition, geological literature includes experimental studies on how elements behave and partition in different types of sulfide/metal/metal alloy-glass systems, related to the formation of the earth's core and crust. These data can provide the first estimations regarding the behavior of multiple elements also for process metallurgists, and the results can also be compared to some extent to minor element distributions in industrial process conditions; the laws of nature hold true in both cases. Geological literature includes quite an extensive amount of studies considering high-tech metals [12-22]. Nevertheless, the number of distribution studies are limited and have been executed in different systems (e.g., Fe-glass) and experimental conditions (higher T, $\mathrm{P}$ and lower $\mathrm{pO}_{2}$ ) than those prevailing in copper smelting processes. Cabobianco et al. [17] investigated $\mathrm{Ga}$ and $\mathrm{Ge}$ partitioning between solid Ni-Fe alloy and eucritic basalt glass in alumina crucibles at $1260{ }^{\circ} \mathrm{C}$ and in $\mathrm{pO}_{2}=10^{-13}-10^{-8}$ atm $(\mathrm{P}=1 \mathrm{~atm})$. Schmitt et al. [18] also studied Ge and $\mathrm{Ga}$ in Ni-Fe alloy and tholeiitic basalt system at $1300^{\circ} \mathrm{C}\left(\mathrm{pO}_{2}=10^{-14}-10^{-10} \mathrm{~atm}\right)$ and $1600{ }^{\circ} \mathrm{C}$ $\left(\mathrm{pO}_{2}=10^{-12}-10^{-8} \mathrm{~atm}\right)$. Two studies found regarding the behavior of gallium between metal and liquid silicates in highly reducing conditions $\left(\mathrm{pO}_{2}=10^{-13}-10^{-12}\right.$ bar, $\mathrm{P} \leq 1$ bar) at 1190 to $1330{ }^{\circ} \mathrm{C}[19,20]$. Mann et al. [21] studied indium and gallium partitioning between Fe-metal and silicate melt at 1750 to $2600{ }^{\circ} \mathrm{C}$ ( $\triangle \mathrm{IW}$ (iron-wustite buffer) from -1.3 to $-4.2,2-24 \mathrm{GPa}$ ). Moreover, Righter et al. [22] investigated volatile siderophile elements germanium and indium partitioning between iron alloy and silicate between $\Delta \mathrm{IW}$ from -0.81 to $-7.1(1 \mathrm{GPa})$ at 1500 to $1900{ }^{\circ} \mathrm{C}$.

To develop and improve the minor element recoveries in smelting processes, more precise data on their behavior is required. This study employs highly advanced and accurate experimental-analytical techniques to determine solute concentrations and/or distribution coefficients of indium, gallium and germanium between metallic copper and silica-saturated iron-silicate slags with additions of slag modifiers $\mathrm{Al}_{2} \mathrm{O}_{3}$ and $\mathrm{CaO}$. The experiments were executed in simulated secondary copper smelting conditions in the oxygen partial pressure range of $10^{-9}$ to $10^{-5} \mathrm{~atm}$ at $1300^{\circ} \mathrm{C}$.

\section{Materials and Methods}

The drop-quench technique employed in this study is already relatively widely used in phase equilibria studies $[23,24]$, and nowadays also in minor element investigations $[25,26]$. The critical steps of the technique include (1) sample precursor preparation, (2) equilibration-quenching experiments and (3) EPMA measurements. The newest step included in the experimental chain is (4) LA-ICP-MS analyses.

The sample precursor preparation was executed by homogenizing a copper master alloy including approximately $1 \mathrm{wt} \%$ of Ga, Ge and In each (Alfa Aesar, purity $>99.99 \%$ ). Furthermore, slag mixtures 
of $\mathrm{Fe}_{2} \mathrm{O}_{3}-\mathrm{SiO}_{2}, \mathrm{Fe}_{2} \mathrm{O}_{3}-\mathrm{SiO}_{2}-10 \mathrm{Al}_{2} \mathrm{O}_{3}$ and $\mathrm{Fe}_{2} \mathrm{O}_{3}-\mathrm{SiO}_{2}-10 \mathrm{Al}_{2} \mathrm{O}_{3}-5 \mathrm{CaO}$ (high purity powders $>99.9 \%$ ) for different conditions were prepared. The preparation processes of copper alloy and slags are described in our previous manuscripts [10] and [27], respectively. Figure 1 represents the calculated phase diagram of copper-free (red lines) and copper-saturated (black lines) $\mathrm{Al}_{2} \mathrm{O}_{3}-\mathrm{SiO}_{2}-\mathrm{FeO}_{\mathrm{x}}$ system superimposed at $1300{ }^{\circ} \mathrm{C}$ and $10^{-5} \mathrm{~atm}$ with the "target point" for copper- and silica-saturated iron-silicate slag including $10 \mathrm{wt} \% \mathrm{Al}_{2} \mathrm{O}_{3}$. The phase assembly of this point is shown in the micrograph of a sample taken from the aforementioned experimental conditions.



Figure 1. One of the slag target points in this study shown in $\mathrm{Al}_{2} \mathrm{O}_{3}-\mathrm{SiO}_{2}-\mathrm{FeO}_{\mathbf{x}}$ phase diagram and in the corresponding sample micrograph. The phase diagram is calculated employing the MTDATA and MTOX database [28].

The phase diagram shows the influence of copper on $\mathrm{Al}_{2} \mathrm{O}_{3}-\mathrm{SiO}_{2}-\mathrm{FeO}_{\mathrm{x}}$ system; it expands and slightly moves the slag (oxide liquid) region downwards from the $\mathrm{SiO}_{2}$ corner. Without copper in the system, the target point of oxide liquid, including $10 \mathrm{wt} \% \mathrm{Al}_{2} \mathrm{O}_{3}$ would not be possible to reach, see the target black line in the figure. The micrograph in Figure 1 includes homogeneous copper and tridymite phases, whereas the slag contains some visible (bright) copper segregations. At high partial pressure of oxygen, $10^{-5} \mathrm{~atm}$, the slag has a high concentration of copper, causing difficulties in quenching the phase into fully homogeneous glass. Note that only pure and alumina-containing iron-silicate slags at $10^{-5} \mathrm{~atm}$, when the concentration of copper in the slag was above $15 \mathrm{wt} \%$, exhibited these copper segregations. Large analysis spots, 20-100 $\mu \mathrm{m}$, were employed in the EPMA analyses for copper and slag, to achieve representative phase composition results including possible segregations and inhomogeneities.

The equilibrium experiments were executed in a vertical resistance furnace manufactured by Nabertherm (RHTV 120-150/18, Lilienthal, Germany) with a Nabertherm P310 temperature controller. The sample materials-copper alloy and slag-were measured as $0.1 \mathrm{~g}$ each and pressed to pellets. The pellets were placed in silica crucibles (Heraeus, HSQ ${ }^{\circledR} 300$ by Finnish Special Glass, Espoo, Finland) and equilibrated for $16 \mathrm{~h}$ at $1300{ }^{\circ} \mathrm{C}$ in an appropriate gas atmosphere $\left(\mathrm{CO}-\mathrm{CO}_{2}\right)$. To end the experiment, the sample was rapidly quenched into ice-water mixture or brine, to maintain and analyze the achieved high-temperature equilibrium assembly and phase compositions at room temperature. The samples were prepared with metallographic methods for SEM-EDS, EPMA and LA-ICP-MS analyses. SEM-EDS (LEO 1450, Zeiss, NY, US) was used to obtain micrographs of the samples, and preliminary analyses were also made to verify that equilibrium had been reached. EPMA (Cameca SX-100, France) was used to measure all the elements present in all the phases. The analyzed lines and standards used were as follows: $\mathrm{Si} \mathrm{K} \alpha$ (quartz), $\mathrm{Al} \mathrm{K} \beta\left(\mathrm{Al}_{2} \mathrm{O}_{3}\right), \mathrm{Cu} \mathrm{K} \alpha(\mathrm{Cu}), \mathrm{Fe} \mathrm{K} \alpha$ (hematite), $\mathrm{Ge} \mathrm{K} \alpha(\mathrm{Ge}), \mathrm{Ga} \mathrm{K} \alpha(\mathrm{GaAs}), \mathrm{O} \mathrm{K} \alpha$ (hematite), $\mathrm{Ca} \mathrm{K} \alpha$ (diopside) and In $\mathrm{L} \alpha$ (InAs). More details on the experimental equipment, execution 
of the experiments and electron microscope settings can be found in our previous publications [10,11]. The detection limits for Ge, Ga and In with EPMA and LA-ICP-MS are presented in Table 1. The EPMA totals of individual points were between 98 and 100.5\%.

Table 1. Detection limits of Ga, Ge and In by EPMA and LA-ICP-MS.

\begin{tabular}{cccc}
\hline & Ga & Ge & In \\
\hline Cu & $211 \mathrm{ppm}$ & $274 \mathrm{ppm}$ & $153 \mathrm{ppm}$ \\
Slag EPMA & $168 \mathrm{ppm}$ & $212 \mathrm{ppm}$ & $124 \mathrm{ppm}$ \\
\hline \multirow{2}{*}{ Slag LA-ICP-MS } & ${ }^{69} \mathrm{Ga},{ }^{71} \mathrm{Ga}$ & ${ }^{74} \mathrm{Ge}$ & ${ }^{115} \mathrm{In}$ \\
& $8.6,9.8 \mathrm{ppb}$ & $34.7 \mathrm{ppb}$ & $2.2 \mathrm{ppb}$ \\
\hline
\end{tabular}

Laser ablation-inductively coupled plasma-mass spectrometry was utilized to analyze gallium, germanium and indium concentrations in metallurgical slags for the first time. This is an in-situ micro sampling technique that can be used for accurate quantification of very low concentrations $(<10 \mathrm{ppb})$ of elements in a wide range of materials, including the glassy phases analyzed here. Geologists and earth scientists have used it for approximately 30 years [29] for analyzing elements in low concentrations in different geomaterials, and to explain their distribution behavior in the formation of earth's crust (e.g., formation of various ore deposit types). Today, the capabilities of the technique for also analyzing metallurgical samples has been acknowledged [30,31]. The equipment used in this study is shown in Figure 2.

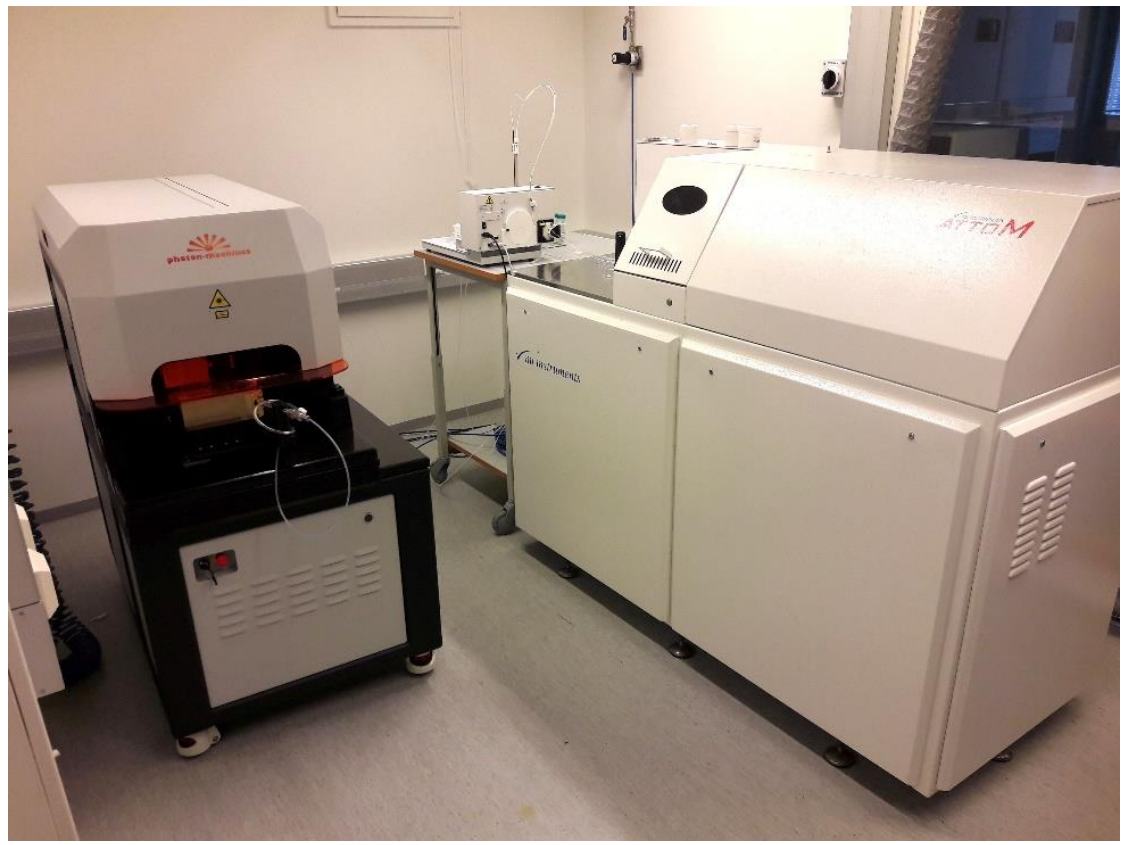

Figure 2. The Analyte Excite ArF laser ablation device, coupled with a Nu Instruments Attom single collector inductively coupled plasma-mass spectrometer.

The equipment (Figure 2) is a Photon Machines Analyte Excite $193 \mathrm{~nm}$ ArF laser ablation device (Teledyne CETAC Technologies, Omaha, NE, USA) coupled with a Nu AttoM single collector ICP-MS (Nu In-struments Ltd., Wrexham, UK), housed at the Geological Survey of Finland. This configuration provides rapid, high quality, in-situ measurements of trace elements in glasses, minerals, sulfides, slags, mattes, spinels, etc. In this study, the laser energy was set to $30 \%$ of $5.0 \mathrm{~mJ}$, resulting in a fluence of $2.5 \mathrm{~J} / \mathrm{cm}^{2}$ on the sample surface. A spot size of $85 \mu \mathrm{m}$ and operating frequency of $10 \mathrm{~Hz}$ were selected. The laser typically ablates a circular pit into the sample, producing micro- to nano-sized particles of the target material which are transferred and introduced to the ICP for ionization, followed by subsequent 
analysis of the ions in the MS based on their mass/charge ratio. The analysis procedure included 5 pre-ablation pulses (for removal of the carbon coating and possible contaminants from the sample surface), $20 \mathrm{~s}$ pause, $20 \mathrm{~s}$ gas background analysis, and 400 ablation pulses. The mass spectrometer was operated in FastScan mode in low resolution $(\Delta M / M=300)$ to maximize sensitivity. Eight ablation points were analyzed from the slag phase of each sample.

NIST 612 and 610 SRM [32] were used as the external standards and Si as the internal standard for the analyses. The GeoREM preferred values [33] for Ga, Ge and In with their standard deviations in both external standards are listed in Table 2. The standard deviations demonstrate the homogeneous spread of the elements-of-interest in the standard NIST glasses. The concentration of silicon was measured with EPMA. NIST 610 SRM or NIST 612 SRM, USGS BHVO-2G and BCR-2G [34] reference glasses were analyzed as unknowns for monitoring the analysis accuracy, which proved to be within $\pm 10 \%$. The time-resolved analysis (TRA) signals collected from the mass spectrometer were analyzed with GLITTER software [35]. The isotopes ${ }^{69,71} \mathrm{Ga},{ }^{70,72,74} \mathrm{Ge}$ and ${ }^{113,115}$ In were analyzed for quantifying the corresponding minor element concentrations. However, some of these have significant interferences causing incorrect concentration values. Gallium isotopes were interference-free, so averages of them ( ${ }^{69}$ and ${ }^{71} \mathrm{Ga}$ ) were used, whereas, for germanium and indium, only one isotope from each was considered interference-free, ${ }^{74} \mathrm{Ge}$ [36] and ${ }^{115} \mathrm{In}$. The average detection limits of the used isotopes, calculated by the GLITTER software, are shown in Table 1. Additionally, samples from a previous study [11] at alumina-iron spinel-saturation were re-analyzed with LA-ICP-MS.

Table 2. Internal concentrations of $\mathrm{Ga}, \mathrm{Ge}$ and In in the external standards used in the LA-ICP-MS measurements [33].

\begin{tabular}{cccc}
\hline Standard & Ga & Ge & In \\
\hline NIST 612 SRM & $36.9 \pm 1.5$ & $36.1 \pm 3.8$ & $38.9 \pm 2.1$ \\
NIST 610 SRM & $433 \pm 13$ & $447 \pm 78$ & $434 \pm 19$ \\
\hline
\end{tabular}

The main purpose of this work was to study the thermodynamic properties of high-tech metals in copper smelting conditions, i.e., their concentrations in the liquid phases and their distribution coefficients. The distribution coefficient, $\mathrm{L}^{\mathrm{Cu} / \mathrm{s}}$, describes the mass ratio of an element between two phases $[w t \% M]_{\text {in copper }} /(w t \% M)$ in slag. The minor element concentrations were low, and thus, they obey Henry's law [37]. The phase compositions and chemistry of the slags were presented in more detail in our other publications $[27,38]$.

\section{Results}

The calculated average concentrations and standard deviations of indium, gallium and germanium in both liquid phases are presented in Table 3. The copper phase was analyzed only with EPMA, whereas the slags were analyzed with EPMA and LA-ICP-MS employing two different external standards (NIST 610 and 612 SRM). The small standard deviations indicate homogeneous phases and lack of concentration gradients, and thus good quenching and equilibrium conditions achieved.

Indium was the only minor element analyzed reliably from the copper phase in all experimental conditions with both techniques. Indium dissolution changed radically when the atmosphere was changed, i.e., in reducing conditions indium dissolved more into copper as a metallic species and in oxidizing conditions into slag as an oxide. The addition of basic/amphoteric oxides seemed to increase the concentration of indium in the copper phase. The concentration of indium in slags increased greatly as a function of increasing oxygen partial pressure. As the phase relations vary with different starting compositions of slags and with different atmospheric $\mathrm{pO}_{2}$, the distribution coefficient describes minor element behavior better than solute concentration values separately. 
Table 3. High-tech metal results in ppmw with both analytical techniques and standards.

\begin{tabular}{|c|c|c|c|c|c|c|c|c|c|c|c|c|c|}
\hline \multirow{2}{*}{ System $^{1}$} & \multirow[t]{2}{*}{$\operatorname{lgpO} O_{2}$} & \multicolumn{3}{|c|}{ Copper Phase } & \multicolumn{3}{|c|}{ Slag Phase, EPMA } & \multicolumn{3}{|c|}{ Slag Phase, LAICPMS 612} & \multicolumn{3}{|c|}{ Slag Phase, LAICPMS 610} \\
\hline & & In & $\mathrm{Ga}^{2}$ & $\mathrm{Ge}$ & In & $\mathrm{Ga}$ & Ge & In & Ga & $\mathrm{Ge}$ & In & $\mathrm{Ga}$ & Ge \\
\hline \multirow[t]{5}{*}{ IS } & -5 & $110 \pm 30$ & 60 & n.d. & $4620 \pm 50$ & $4180 \pm 110$ & n.d. & $3970 \pm 100$ & $3310 \pm 80$ & $4.2 \pm 0.5$ & $4170 \pm 110$ & $3630 \pm 90$ & $4.4 \pm 0.5$ \\
\hline & & $160 \pm 40$ & 40 & n.d. & $4950 \pm 60$ & $4670 \pm 120$ & n.d. & & & & & & \\
\hline & -7 & $840 \pm 50$ & 70 & n.d. & $1290 \pm 100$ & $5920 \pm 150$ & n.d. & $1130 \pm 30$ & $4690 \pm 70$ & $0.8 \pm 0.2$ & $1160 \pm 30$ & $5000 \pm 100$ & $0.8 \pm 0.2$ \\
\hline & & $690 \pm 80$ & 30 & n.d. & $990 \pm 50$ & $6110 \pm 60$ & n.d. & & & & & & \\
\hline & -9 & $1790 \pm 130$ & $460 \pm 60$ & n.d. & $130 \pm 20$ & $4420 \pm 70$ & n.d. & $120 \pm 10$ & $4330 \pm 50$ & $0.5 \pm 0.3$ & $130 \pm 10$ & $3760 \pm 60$ & $0.5 \pm 0.3$ \\
\hline \multirow[t]{6}{*}{ IS $+\mathrm{A}$} & -5 & $270 \pm 70$ & 40 & n.d. & $4310 \pm 90$ & $4390 \pm 80$ & n.d. & $3850 \pm 90$ & $3600 \pm 80$ & $0.5 \pm 0.2$ & $3970 \pm 100$ & $3840 \pm 90$ & $0.5 \pm 0.2$ \\
\hline & & $220 \pm 80$ & 40 & n.d. & $4190 \pm 40$ & $4430 \pm 50$ & n.d. & & & & & & \\
\hline & -7 & $2000 \pm 150$ & 90 & n.d. & $2700 \pm 70$ & $6070 \pm 50$ & n.d. & $2400 \pm 60$ & $4910 \pm 130$ & $1.3 \pm 0.8$ & $2490 \pm 70$ & $5280 \pm 130$ & $1.4 \pm 0.8$ \\
\hline & & $1590 \pm 160$ & 50 & n.d. & $2120 \pm 120$ & $6310 \pm 70$ & n.d. & & & & & & \\
\hline & -9 & $3430 \pm 450$ & $660 \pm 40$ & n.d. & $340 \pm 70$ & $5390 \pm 80$ & n.d. & $330 \pm 40$ & $4190 \pm 80$ & $1.9 \pm 1.5$ & $340 \pm 40$ & $4590 \pm 90$ & $2.0 \pm 1.6$ \\
\hline & & $3410 \pm 150$ & $670 \pm 50$ & n.d. & $360 \pm 70$ & $5530 \pm 90$ & n.d. & & & & & & \\
\hline \multirow[t]{6}{*}{$\mathrm{IS}+\mathrm{AC}$} & -5 & $240 \pm 70$ & 80 & n.d. & $3820 \pm 120$ & $3850 \pm 110$ & n.d. & $3500 \pm 150$ & $3520 \pm 110$ & $0.5 \pm 0.2$ & $3660 \pm 150$ & $3860 \pm 120$ & $0.5 \pm 0.2$ \\
\hline & & $300 \pm 120$ & 50 & n.d. & $4150 \pm 90$ & $4480 \pm 60$ & n.d. & & & & & & \\
\hline & -7 & $1500 \pm 150$ & 80 & n.d. & $1680 \pm 70$ & $4940 \pm 160$ & n.d. & $1490 \pm 90$ & $4600 \pm 110$ & $1.4 \pm 1.1$ & $1560 \pm 90$ & $4960 \pm 100$ & $1.5 \pm 1.2$ \\
\hline & & $1660 \pm 90$ & 60 & n.d. & $2030 \pm 60$ & $5800 \pm 110$ & n.d. & & & & & & \\
\hline & -9 & $4090 \pm 380$ & $370 \pm 70$ & n.d. & $290 \pm 20$ & $5630 \pm 90$ & n.d. & $250 \pm 10$ & $4510 \pm 80$ & $0.9 \pm 0.4$ & $260 \pm 10$ & $4930 \pm 90$ & $0.9 \pm 0.5$ \\
\hline & & $3240 \pm 330$ & $380 \pm 70$ & n.d. & $270 \pm 50$ & $5630 \pm 80$ & n.d. & & & & & & $4.4 \pm 0.5$ \\
\hline
\end{tabular}

1. IS refers to pure iron-silicate slag. IS+A to iron-silicate slag including $10 \mathrm{wt} \%$ alumina and IS+AC to iron-silicate slag including $10 \mathrm{wt} \% \mathrm{alumina}$ and $5 \mathrm{wt} \%$ lime. ${ }^{2} \mathrm{Ga}$ concentration values at the level of $<100 \mathrm{ppm}$ are below the detection limit. 
Gallium concentration in copper was above the detection limit only at $\mathrm{pO}_{2} 10^{-9} \mathrm{~atm}$, and the concentration of germanium fell below the detection limit of EPMA in all conditions in both copper and slag phases. LA-ICP-MS was capable of measuring the concentration of germanium in slags, and the external standard used did not seem to have an influence on the measured concentrations. In general, the concentration of germanium in NIST 612 is closer to the concentration in the analyzed samples. Thus, it can be considered to provide more accurate results.

Comparison between the analytical techniques must be made by acknowledging the strengths of both techniques and the optimal concentration ranges of the selected standard reference materials. Trace element concentrations of $>1000 \mathrm{ppm}$ are twofold or even higher than the concentrations in the external standards selected for LA-ICP-MS analysis (see Table 2), thus potentially explaining the difference from the EPMA results. Another reason for the difference between EPMA and LA-ICP-MS results for In and Ga might have been caused by the different volatility of elements in the standard material and the samples during the LA-ICP-MS analyses. In the case of gallium in slags, EPMA data are roughly $15 \%$ higher than the LA-ICP-MS data. However, since the laser was unable to ablate nearly pure $\mathrm{Cu}$ metal, the copper phase data are only from the EPMA, and hence, for consistency, only EPMA data are used for $\mathrm{Ga}$ in the distribution calculations presented here. The error bars shown in the graphs (Figures 4 and 5) represent standard uncertainties of the experimental data $(1 \sigma)$.

Some estimations on the evaporation level can be done from these concentration results presented in Table 3. Germanium was clearly evaporated almost entirely, $>99 \%$, as the concentrations in both liquid phases were below the detection limits of EPMA. In addition, it seems that large percentages of indium and gallium were evaporated, although the mass balances cannot be calculated accurately (requires a very large number of assumptions). In industrial processes, the vaporization is greatly dependent on the technology used, but the distribution coefficients between copper and slag are independent of the smelting technology. Thus, this study approached the recoveries and behavior of minor elements mainly from the measured concentrations and calculated distribution coefficients in liquid phases.

\section{Discussion}

The distribution coefficients of indium as a function of oxygen partial pressure and slag composition are presented in Figure 3. Both analytical techniques were capable of analyzing reliably the concentrations of indium in slags, and thus, comparative distribution coefficients were plotted in the figure. For LA-ICP-MS, the slag results have been calculated based on the measurements employing the NIST 610 standard, wherein the indium concentration was closer to the slags analyzed.

As can be seen, the In distribution coefficients and their trends are identical within error, independent of the analytical technique used for the slags. The distribution coefficient of indium was highly dependent on the oxygen partial pressure: in reducing conditions indium dissolves more into black copper, but after the converting stage it is mainly oxidized into the slag. If the converter slag is treated only by recirculating it back into the reduction stage, indium will accumulate into this slag circuit. Thus, the converting slag should be treated for indium recovery before recirculating. Indium evaporation is also recognized in our results and in industrial copper smelting [39-41]. Furthermore, old patents [42,43] for indium, germanium and gallium recovery technologies employ their evaporation tendencies, as pointed out in our recent papers for many trace elements [27,44]. Alumina addition did not influence the distribution coefficient, whereas the addition of lime increased it slightly. The slopes of the plots with pure iron-silicate slag are close to 0.7 , whereas for alumina and alumina-lime containing slags they are 0.5 to 0.6 . These slopes indicate di- and/or tri-valent forms of dissolved indium oxide in the slags. The distribution coefficients of indium between copper and slag obtained in earlier studies $[11,45,46]$ fit well with our results. Moreover, the increasing influence on $\mathrm{L}^{\mathrm{Cu} / \mathrm{s}}$ by lime was also observed previously [46]. Geological literature on indium is not directly comparable with our results, although Righter et al. [22] measured indium distribution between liquid Fe and a silicate glass 
as a function of temperature from $1500{ }^{\circ} \mathrm{C}$ to $1900{ }^{\circ} \mathrm{C}$ at $\Delta \mathrm{IW} \sim 1.4$. Their distribution coefficients were between 0.1 and 1 , which are in the same order of magnitude as ours.

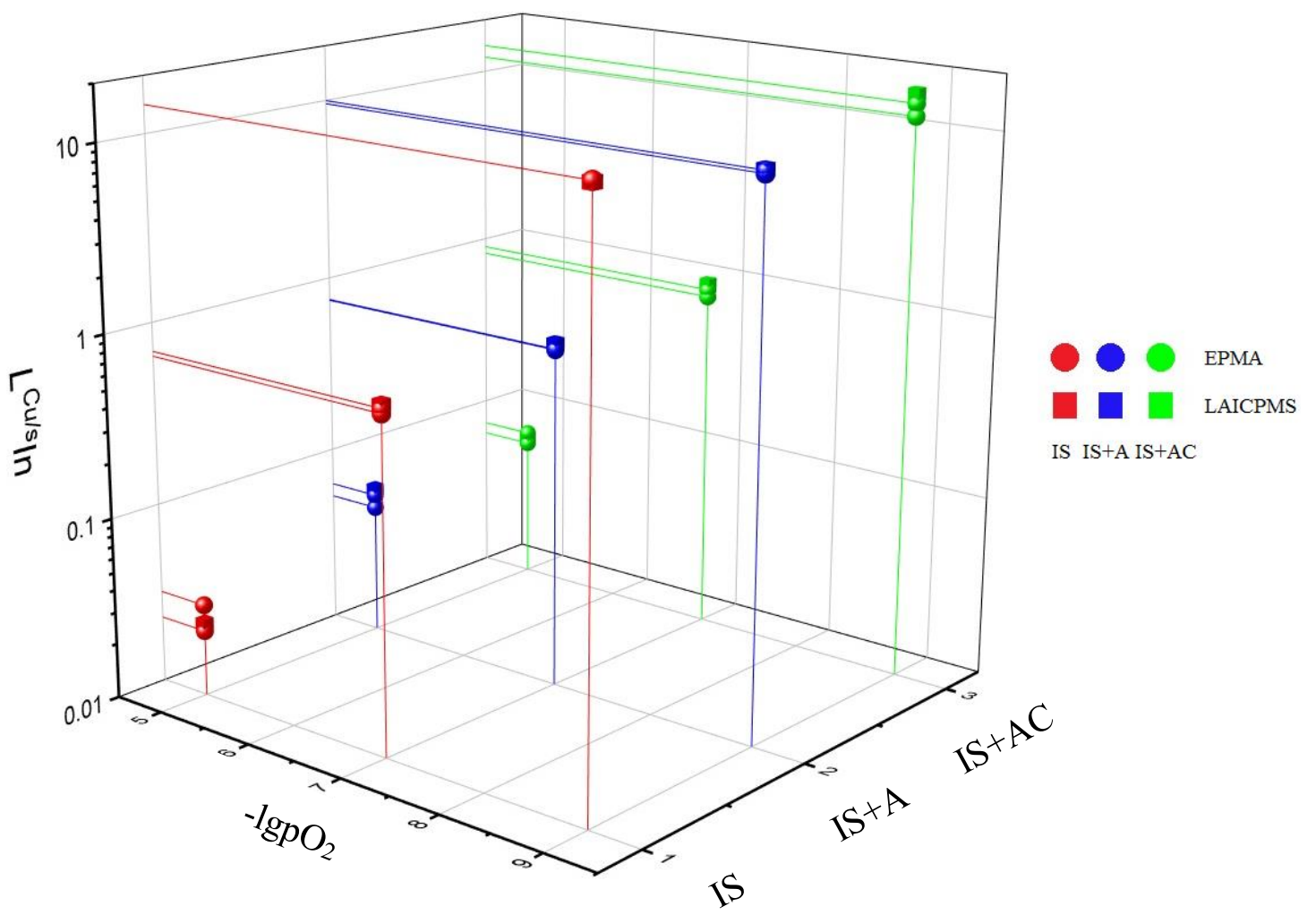

Figure 3. Distribution coefficient of indium as a function of $\mathrm{pO}_{2}$ and slag composition at $1300{ }^{\circ} \mathrm{C}$. Red symbols indicate pure iron-silicate slag (IS), blue represents iron-silicate slag including $10 \mathrm{wt} \%$ alumina (IS+A) and green symbols refer to iron-silicate slag with $10 \mathrm{wt} \%$ alumina and $5 \mathrm{wt} \%$ lime (IS+AC). Moreover, round symbols indicate to distribution coefficients calculated from the EPMA results of indium in slags and cube symbols to LA-ICP-MS results of indium in slags.

The distribution coefficient of gallium as a function of oxygen partial pressure with calculated uncertainties is presented in Figure 4, as well as the distribution results from our previous study [11] at spinel-saturation and a few geological partitioning results between Ni-Fe and silicate glass $[17,18]$. A trend line representing the $\mathrm{Ga}^{3+}$ form as oxide $\mathrm{GaO}_{1.5}$ is also drawn on the figure. Only EPMA results were employed for calculating these distribution coefficients. Overall, the concentration of gallium in the copper alloy was below the detection limit at partial pressures $>10^{-8} \mathrm{~atm}$. This can be seen from the changing slope of the plot at $10^{-7}$ atm (Figure 4), and larger uncertainties and experimental scatter compared to the $10^{-8}$ to $10^{-10} \mathrm{~atm}$ range [11]. Thus, the trend line to evaluate the oxidation degree $\left(\mathrm{Ga}^{3+}\right)$ was done according to the results of this study and our previous study [11] at low partial pressures $\leq 10^{-8} \mathrm{~atm}$.

The distribution results fit well with our previous study, and also with geological studies between Fe-Ni metal and silicate glasses $[17,18]$. Geological studies and the previous metallurgical study at spinel-saturation [11] indicate $\mathrm{Ga}^{3+}\left(\mathrm{GaO}_{1.5}\right)$ dissolution form in silicate melts and slags. No influence by different silicate slag compositions nor metal phase compositions ( $\mathrm{Ni}-\mathrm{Fe}$ or $\mathrm{Cu}$ ) on the distribution coefficient were observed. The distribution coefficient is dependent on the oxygen partial pressure, but under both reducing and oxidizing smelting conditions gallium was distributed more into the slag phase. Thus, its recovery should be accomplished by treating the smelting and converting slags, and depending on the smelting technology used, possibly from dusts and/or fumes as well. 




Figure 4. Distribution coefficient of gallium as a function of oxygen partial pressure at $1300{ }^{\circ} \mathrm{C}$. The black trend line indicates an oxidation state of $\mathrm{Ga}^{3+}\left(\mathrm{GaO}_{1.5}\right)$.

The concentration of germanium was below the detection limit of EPMA in both phases. This result indicates high volatilization of germanium, as also suggested in our previous study [11]. The volatile nature of germanium was also acknowledged in geological studies and by industry $[47,48]$. Figure 5 presents solute concentrations of germanium in slags with the standard deviations according to LA-ICP-MS; in addition, the re-analyzed spinel-saturated iron-silicate slag results [11] were added to Figure 5. The concentrations at silica-saturation were shown to be around $1 \mathrm{ppm}$ without a clear trend as a function of $\mathrm{pO}_{2}$.

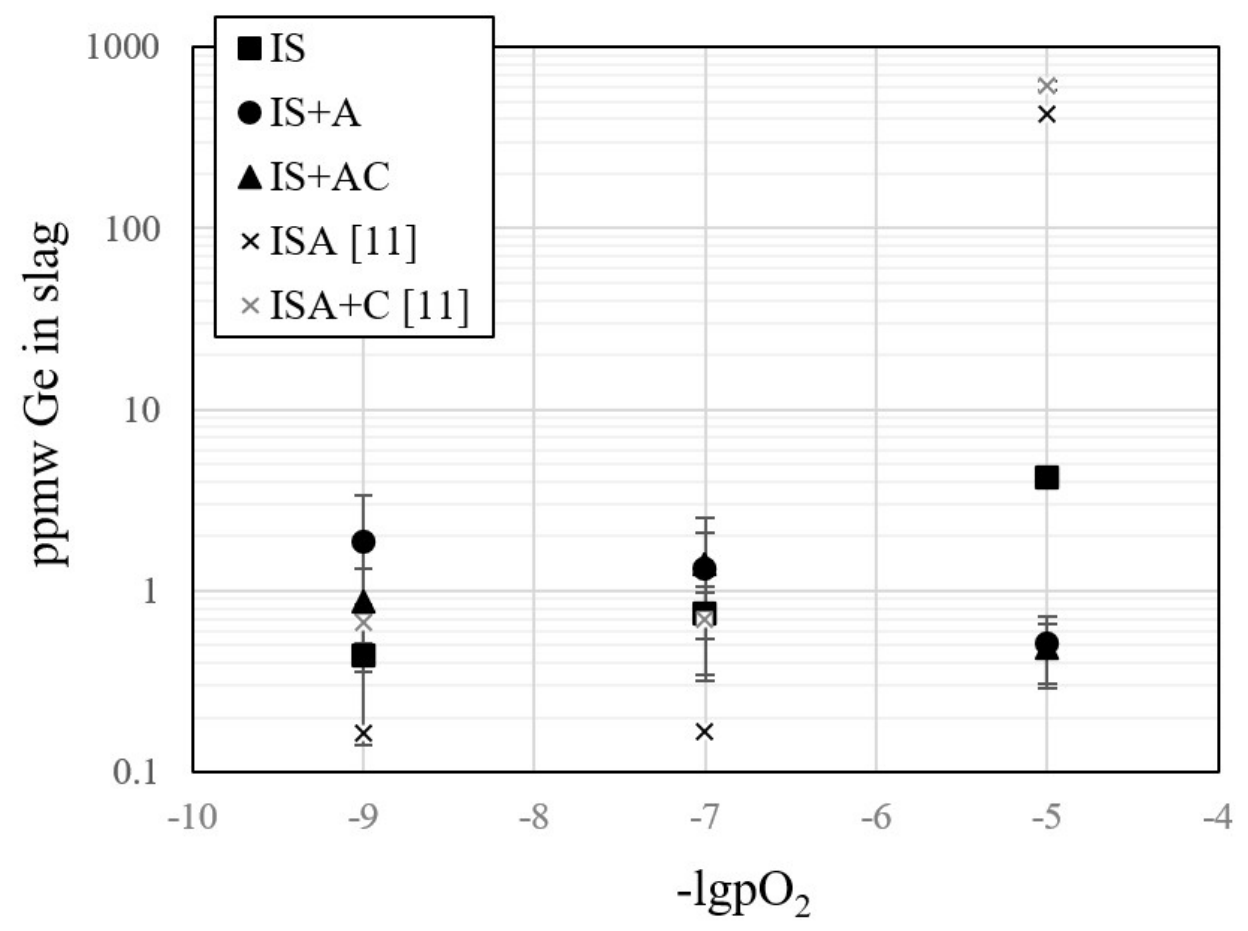

Figure 5. The concentration of germanium in different iron-silicate based slags as a function of oxygen partial pressure at $1300^{\circ} \mathrm{C}$. ISA and ISA+C indicate to iron-silicate slags, including $~ 15-20 \mathrm{wt} \%$ alumina (ISA) and $~ 15-20 \mathrm{wt} \%$ alumina and $5 \mathrm{wt} \%$ lime (ISA+C) [11]. 
As no reliable concentration results were obtained for germanium in the copper phase, the maximum distribution coefficient, i.e., "limiting coefficient", can be evaluated as follows:

$$
\begin{aligned}
\max \mathrm{L}^{\mathrm{Cu} / \mathrm{s}}[\mathrm{Ge}]= & \frac{[\text { Detection limit of Ge by EPMA }]_{\text {in copper }}}{(\text { Measured concentration of Ge by LA }-\mathrm{ICP}-\mathrm{MS})_{\text {in slag }}} \\
& =\frac{274 \mathrm{ppm}}{0.5-5 \mathrm{ppm}}=55-548 .
\end{aligned}
$$

Previous publications regarding the behavior of germanium in copper smelting at $1300{ }^{\circ} \mathrm{C}$ show distribution coefficients of 4 to 0.4 [11] in the $\mathrm{pO}_{2}$ range of $10^{-10}-10^{-5}$ atm and 50 to 0.2 at $\mathrm{pO}_{2} 10^{-10}-10^{-7} \mathrm{~atm}$ [49]. Research conducted in lead smelting conditions shows lower distribution coefficients $\left(\mathrm{L}^{\mathrm{Pb} / \mathrm{s}} \mathrm{Ge}\right)$ of 0.1 to 0.001 at $\mathrm{pO}_{2} 10^{-12}-10^{-8}$ atm $[50,51]$. Geological studies have presented distribution coefficients of 1000 to 3 at $\mathrm{pO}_{2}$ range $10^{-12}-10^{-8} \mathrm{~atm}\left(1260^{\circ} \mathrm{C}\right)$ [17] and 10,000 to 100 at $\mathrm{pO}_{2}$ range $10^{-10}-10^{-14} \mathrm{~atm}\left(1300^{\circ} \mathrm{C}\right)$ [18] between $\mathrm{Ni}-\mathrm{Fe}$ metal and silicate glasses. The previous results from lead and copper smelting experiments suggest both divalent $\mathrm{Ge}^{2+}(\mathrm{GeO})$ and tetravalent $\mathrm{Ge}^{4+}$ $\left(\mathrm{GeO}_{2}\right)$ forms, respectively. A geological study by Cabobianco et al. [17] suggests a tetravalent $\mathrm{Ge}^{4+}$ form $\left(\mathrm{GeO}_{2}\right)$ with $\mathrm{pO}_{2}=10^{-10}-10^{-8}$ atm at $1300{ }^{\circ} \mathrm{C}$, and several other studies $[15,18,47]$ suggest di- or trivalent $\left(\mathrm{Ge}^{2+}\right.$ or $\left.\mathrm{Ge}^{3+}\right)$ forms in highly reducing conditions.

\section{Conclusions}

Securing the high-tech metal supply requires the optimization of primary and secondary production of base metals as well as improved characterization of the thermodynamic properties of high-tech metals. In this study, a multidisciplinary approach for investigating the behavior of $\mathrm{Ga}, \mathrm{Ge}$ and In was employed: An analytical technique more typical in geology was used for metallurgical slags, and the results obtained were compared to existing geological literature. The behavioral properties of high-tech metals in copper-slag systems were characterized at $1300{ }^{\circ} \mathrm{C}$ in the oxygen partial pressure range of $10^{-9}-10^{-5} \mathrm{~atm}$. The experiments were conducted employing a drop-quench technique followed by direct phase analyses with EPMA and LA-ICP-MS. The data obtained show that the distribution coefficient of indium decreased as a function of increasing oxygen partial pressure, providing improved recovery possibilities in copper under reducing conditions, $\mathrm{L}^{\mathrm{Cu} / \mathrm{s}} \approx 10$. After oxidizing converting, the slag needs to be treated for indium recovery. Lime has a positive influence on the recovery of indium in copper. In condensed phases, gallium distributes strongly in the slag, and only at $10^{-9} \mathrm{~atm}$ its distribution coefficient was measured reliably as 0.1 . The recovery of gallium, according to the distribution coefficient, needs to be executed from the smelting and converting slags. Results are in the same level with previous geological studies on gallium behavior in Fe-Ni-silicate glass systems. Germanium was vaporized almost entirely in the copper smelting conditions investigated. Its concentrations in the slag were measured with LA-ICP-MS around 1 ppm.

Author Contributions: Conceptualization, K.A. and P.T.; methodology, K.A., L.K. and P.T.; validation, K.A., L.K., H.O., P.T. and A.J.; formal analysis, K.A.; investigation, K.A., L.K. and H.O.; resources, A.J., P.T. and H.O.; writing—original draft preparation, K.A.; writing—review and editing, L.K., H.O., P.T. and A.J.; visualization, K.A.; supervision, P.T. and A.J.; funding acquisition, K.A., L.K., P.T. and A.J.

Funding: The authors would like to thank Alfred Kordelin (K.A.), Emil Aaltonen (K.A.) and the Finnish Steel and Metal Producers' (L.K.) foundations for financial support.

Acknowledgments: This study utilized the Academy of Finland's RawMatTERS Finland Infrastructure (RAMI), based jointly at Aalto University, GTK Espoo and VTT Espoo. The work of Lassi Pakkanen of Geological Survey of Finland in conducting the EPMA analyses is greatly appreciated.

Conflicts of Interest: The authors declare no conflict of interest. The funders had no role in the design of the study; in the collection, analyses, or interpretation of data; in the writing of the manuscript, or in the decision to publish the results. 


\section{References}

1. Oguchi, M.; Murakami, S.; Sakanakura, H.; Kida, A.; Kameya, T. A preliminary categorization of end-of-life electrical and electronic equipment as secondary metal resources. Waste Manag. 2011, 31, 2150-2160. [CrossRef] [PubMed]

2. Ghosh, B.; Ghosh, M.K.; Parhi, P.; Mukherjee, P.S.; Mishra, B.K. Waste printed circuit boards recycling: An extensive assessment of current status. J. Clean. Prod. 2015, 94, 5-19. [CrossRef]

3. Holgersson, S.; Steenari, B.M.; Björkman, M.; Cullbrand, K. Analysis of the metal content of small-size Waste Electric and Electronic Equipment (WEEE) printed circuit boards-Part 1: Internet routers, mobile phones and smartphones. Resour. Conserv. Recycl. 2018, 133, 300-308. [CrossRef]

4. Swain, B.; Mishra, C.; Kang, L.; Park, K.S.; Lee, C.G.; Hong, H.S. Recycling process for recovery of gallium from $\mathrm{GaN}$ an e-waste of LED industry through ball milling, annealing and leaching. Environ. Res. 2015, 138, 401-408. [CrossRef] [PubMed]

5. Kaya, M. Recovery of metals and nonmetals from electronic waste by physical and chemical recycling processes. Waste Manag. 2016, 57, 64-90. [CrossRef]

6. Lehner, T. Integrated recycling of non-ferrous metals at Boliden Ltd. Rönnskar smelter. In Proceedings of the 1998 IEEE International Symposium on Electronics and the Environment, Oak Brook, IL, USA, 6 May 1998; pp. 42-47.

7. Hagelüken, C. Recycling of electronic scrap at Umicore's integrated metals smelter and refinery. Erzmetall 2006, 59, 152-161.

8. Nakamura, T. E-scrap recycling system and technologies in Japan. Geosystem Eng. 2014, 17, 104-112. [CrossRef]

9. Ayres, R.U.; Peiró, L.T. Material efficiency: Rare and critical metals. Phil. Trans. R. Soc. A 2013, 371, 20110563. [CrossRef]

10. Avarmaa, K.; Yliaho, S.; Taskinen, P. Indium, gallium and tin distributions between copper and slag in WEEE smelting conditions. In Proceedings of the European Metallurgical Conference (EMC) 2017, Leipzig, Germany, 25-28 June 2017; pp. 1485-1500.

11. Avarmaa, K.; Yliaho, S.; Taskinen, P. Recoveries of rare elements Ga, Ge, In and Sn from waste electric and electronic equipment through secondary copper smelting. Waste Manag. 2017, 71, 400-410. [CrossRef]

12. Frenzel, M.; Hirsch, T.; Gutzmer, J. Gallium, germanium, indium, and other trace and minor elements in sphalerite as a function of deposit type-A meta-analysis. Ore Geol. Rev. 2016, 76, 52-78. [CrossRef]

13. Paradis, S. Indium, germanium and gallium in volcanic-and sediment-hosted base-metal sulphide deposits. In Proceedings of the Symposium on Strategic and Critical Materials Proceedings, Victoria, BC, Canada, 13-14 November 2015; pp. 23-29.

14. Yi, W.; Halliday, A.N.; Lee, D.C.; Christensen, J.N. Indium and tin in basalts, sulfides, and the mantle. Geochim. Cosmochim. Acta 1995, 59, 5081-5090. [CrossRef]

15. Siebert, J.; Corgne, A.; Ryerson, F.J. Systematics of metal-silicate partitioning for many siderophile elements applied to Earth's core formation. Geochim. Cosmochim. Acta 2011, 75, 1451-1489. [CrossRef]

16. Holzapfel, C.; Courtial, P.; Dingwell, D.B.; Chakraborty, S.; Palme, H. Experimental determination of partial molar volumes of $\mathrm{Ga}_{2} \mathrm{O}_{3}$ and $\mathrm{GeO}_{2}$ in silicate melts: Implications for the pressure dependence of metal-silicate partition coefficients. Chem. Geol. 2001, 174, 33-49. [CrossRef]

17. Capobianco, C.J.; Drake, M.J.; De'Aro, J. Siderophile geochemistry of Ga, Ge, and Sn: Cationic oxidation states in silicate melts and the effect of composition in iron-nickel alloys. Geochim. Cosmochim. Acta 1999, 63, 2667-2677. [CrossRef]

18. Schmitt, W.; Palme, H.; Wänke, H. Experimental determination of metal/silicate partition coefficients for $\mathrm{P}, \mathrm{Co}, \mathrm{Ni}, \mathrm{Cu}, \mathrm{Ga}, \mathrm{Ge}, \mathrm{Mo}$, and $\mathrm{W}$ and some implications for the early evolution of the Earth. Geochim. Cosmochim. Acta 1989, 53, 173-185. [CrossRef]

19. Drake, M.J.; Newsom, H.E.; Reed, S.J.; Enright, M.C. Experimental determination of the partitioning of gallium between solid iron metal and synthetic basaltic melt: Electron and ion microprobe study. Geochim. Cosmochim. Acta 1984, 48, 1609-1615. [CrossRef]

20. Jones, J.H.; Drake, M.J. Geochemical constraints on core formation in the Earth. Nature 1986, 322, 221. [CrossRef] 
21. Mann, U.; Frost, D.J.; Rubie, D.C. Evidence for high-pressure core-mantle differentiation from the metal-silicate partitioning of lithophile and weakly-siderophile elements. Geochim. Cosmochim. Acta 2009, 73, 7360-7386. [CrossRef]

22. Righter, K.; Nickodem, K.; Pando, K.; Danielson, L.; Boujibar, A.; Righter, M.; Lapen, T.J. Distribution of $\mathrm{Sb}, \mathrm{As}, \mathrm{Ge}$, and In between metal and silicate during accretion and core formation in the Earth. Geochim. Cosmochim. Acta 2017, 198, 1-16. [CrossRef]

23. Hidayat, T.; Henao, H.M.; Hayes, P.C.; Jak, E. Phase equilibria studies of Cu-O-Si systems in equilibrium with air and metallic copper and $\mathrm{Cu}-\mathrm{Me}-\mathrm{O}-\mathrm{Si}$ systems $(\mathrm{Me}=\mathrm{Ca}, \mathrm{Mg}, \mathrm{Al}$, and $\mathrm{Fe})$ in equilibrium with metallic copper. Metall. Mater. Trans. B 2012, 43, 1290-1299. [CrossRef]

24. Zhang, R.; Taskinen, P. A phase equilibria study and thermodynamic assessment of the $\mathrm{BaO}-\mathrm{Al}_{2} \mathrm{O}_{3}$ system. Calphad 2015, 51, 42-50. [CrossRef]

25. Avarmaa, K.; Klemettinen, L.; O’Brien, H.; Taskinen, P. Urban mining of precious metals via oxidizing copper smelting. Miner. Eng. 2019, 133, 95-102. [CrossRef]

26. Klemettinen, L.; Avarmaa, K.; Taskinen, P.; Jokilaakso, A. Behavior of nickel as a trace element and time-dependent formation of spinels in WEEE smelting. In Proceedings of the Extraction 2018, Ottawa, ON, Canada, 26-29 August 2018; pp. 1073-1082.

27. Avarmaa, K.; Taskinen, P. The influence of aluminum on indium and tin behaviour during secondary copper smelting. In Proceedings of the Exctraction 2018, Ottawa, ON, Canada, 26-29 August 2018; pp. 1061-1071.

28. Gisby, J.; Taskinen, P.; Pihlasalo, J.; Li, Z.; Tyrer, M.; Pearce, J.; Avarmaa, K.; Björklund, P.; Davies, H.; Korpi, M.; et al. MTDATA and the prediction of phase equilibria in oxide systems: 30 years of industrial collaboration. Metall. Mater. Trans. B 2017, 48, 91-98. [CrossRef]

29. Sylvester, P.J.; Jackson, S.E. A brief history of laser ablation inductively coupled plasma mass spectrometry (LA-ICP-MS). Elements 2016, 12, 307-310. [CrossRef]

30. Avarmaa, K.; O’Brien, H.; Johto, H.; Taskinen, P. Equilibrium distribution of precious metals between slag and copper matte at $1250-1350{ }^{\circ}$ C. J. Sustain. Metall. 2015, 1, 216-228. [CrossRef]

31. Sukhomlinov, D.; Klemettinen, L.; Jokilaakso, A.; Taskinen, P. Indium and iridium partitioning between copper matte and iron silicate slag. In Proceedings of the European Metallurgical Conference, Düsseldorf, Germany, 23-26 June 2019.

32. Jochum, K.; Weis, U.; Stoll, B.; Kuzmin, D.; Yang, Q.; Raczek, I.; Günther, D. Determination of reference values for NIST SRM 610-617 glasses following ISO guidelines. Geostand. Geoanal. Res. 2011, 35, 397-429. [CrossRef]

33. GeoREM. Available online: http://georem.mpch-mainz.gwdg.de/sample_query_pref.asp (accessed on 15 April 2019).

34. Jochum, K.; Willbold, M.; Raczek, I.; Stoll, B.; Herwig, K. Chemical characterization of the USGS reference glasses GSA-1G, GSC-1G, GSD-1G, GSE-1G, BCR-2G, BHVO-2G and BIR-1G using EPMA, ID-TIMS ID-ICP-MS and LA-ICP-MS. Geostand. Geoanal. Res. 2005, 29, 285-302. [CrossRef]

35. Van Achterbergh, E.; Ryan, C.G.; Jackson, S.E.; Griffin, W.L. Data reduction software for LA-ICP-MS. In Laser Ablation-ICP-Mass Spectrometry in the Earth Sciences: Principles and Applications; Short Course Series; Mineralogical Association of Canada: Ottawa, ON, Canada, 2001; Volume 29, pp. 239-243.

36. Belissont, R.; Boiron, M.C.; Luais, B.; Cathelineau, M. LA-ICP-MS analyses of minor and trace elements and bulk Ge isotopes in zoned Ge-rich sphalerites from the Noailhac-Saint-Salvy deposit (France): Insights into incorporation mechanisms and ore deposition processes. Geochim. Cosmochim. Acta 2014, 126, 518-540. [CrossRef]

37. Yazawa, A.; Nakazawa, S.; Takeda, Y. Distribution behavior of various elements in copper smelting systems. Adv. Sulfide Smelt. 1983, 1, 99-117. [CrossRef]

38. Avarmaa, K.; Klemettinen, L.; O'Brien, H.; Taskinen, P. The behavior of tin in black copper smelting conditions with different iron-silicate based slags. In Proceedings of the European Metallurgical Conference, Düsseldorf, Germany, 23-26 June 2019.

39. Germani, M.S.; Small, M.; Zoller, W.H.; Moyers, J.L. Fractionation of elements during copper smelting. Environ. Sci. Technol. 1981, 15, 299-305. [CrossRef]

40. Ke, J.J.; Qiu, R.; Chen, C.Y. Recovery of metal values from copper smelter flue dust. Hydrometallurgy 1984, 12, 217-224. [CrossRef] 
41. Makipirtti, S.A. Process for the Refining of Sulfidic Complex and Mixed Ores or Concentrates. U.S. Patent No 4,169,725, 2 October 1979.

42. Rick, C.E. Production of Group IV-A Metals. U.S. Patent No. 2,773,787, 11 December 1956.

43. Lisowyj, B.; Hitchcock, D.C.; Epstein, H. Process for the Recovery of Gallium and Germanium from Coal Fly Ash. U.S. Patent No. 4,678,647, 7 July 1987.

44. Klemettinen, L.; Avarmaa, K.; Taskinen, P. Trace element distributions in black copper smelting. Erzmetall 2017, 70, 257-264.

45. Sukhomlinov, D.; Avarmaa, K.; Virtanen, O.; Taskinen, P.; Jokilaakso, A. Slag-copper equilibria of selected trace elements in black-copper smelting. Part II. Trace element distributions. Miner. Process. Extr. Metall. Rev. 2019. Accepted for publication (10 April 2019).

46. Anindya, A.; Swinbourne, D.R.; Reuter, M.A.; Matusewicz, R.W. Distribution of elements between copper and $\mathrm{FeO}_{x}-\mathrm{CaO}-\mathrm{SiO}_{2}$ slags during pyroprocessing of WEEE: Part 2-indium. Miner. Process. Extr. Metall. 2014, 123, 43-52. [CrossRef]

47. Kegler, P.; Holzheid, A. Determination of the formal Ge-oxide species in silicate melts at oxygen fugacities applicable to terrestrial core formation scenarios. Eur. J. Mineral. 2011, 23, 369-378. [CrossRef]

48. Morales, P.; Aravena, J.; Salas, J.; Sanchez, G.; Roman, J. Germanium, rhenium and selenium: New valuable by-products to be recovered at Chuquicamata. In Proceedings of the Copper 1991, Hydrometallurgy and Electrometallurgy of Copper, Ottawa, ON, Canada, 18-21 August 1991; pp. 269-280.

49. Shuva, M.A.H.; Rhamdhani, M.A.; Brooks, G.A.; Masood, S.; Reuter, M.A. Thermodynamics behavior of germanium during equilibrium reactions between $\mathrm{FeO}_{\mathrm{x}}-\mathrm{CaO}-\mathrm{SiO}_{2}-\mathrm{MgO}$ slag and molten copper. Metall. Mater. Trans. B 2016, 47, 2889-2903. [CrossRef]

50. Yan, S.; Swinbourne, D.R. Distribution of germanium under lead smelting conditions. Miner. Process. Extr. Metall. 2003, 112, 75-80. [CrossRef]

51. Henao, H.M.; Hayes, P.C.; Jak, E.; Richards, G.G. Research on indium and germanium distributions between lead bullion and slag at selected process conditions. In Proceedings of the Lead Zinc 2010, Vancouver, BC, Canada, 3-6 October 2010; pp. 1145-1160.

(C) 2019 by the authors. Licensee MDPI, Basel, Switzerland. This article is an open access article distributed under the terms and conditions of the Creative Commons Attribution (CC BY) license (http://creativecommons.org/licenses/by/4.0/). 